\title{
State-political and people's collaborationism in Europe in the Second World War period
}

\author{
Yuriy Kazantsev ${ }^{1, *}$ \\ ${ }^{1}$ Novosibirsk State University of Architecture and Civil Engineering (Sibstrin), 113, Leningradskaya \\ str., Novosibirsk, 630008, Russia
}

\begin{abstract}
Impedance coatings of cylindrical bodies' synthesis in order to The authors of the article made an attempt to reveal the main causes and motives of mass collaboration in European countries during the Second World War. Mentally, European man has recognized himself as part of a single space for centuries, under one-man rule: the Roman Empire, the Empire of Charlemagne, and the Holy Roman Empire. The imperial idea initially suggested the European peoples' unification under the auspices of a strong center. The second component of the European mentality was built on the idea of Eurocentrism, proclaiming the superiority of European nations over others, and Western European civilization over the rest of the world. The ruling elite of the German Empire made plans to create "Middle Europe", proclaimed in 1871, which incorporated the economic union of Germany, Austria-Hungary, Belgium, Holland, Denmark, Poland and trimmed France. In 1923, a new idea was published in the manifesto of an Austrian political scientist, Kudenhove-Kalergi - "pan-Europe." The author meant a new, political, single space, spoke about pan-Europe. At the beginning of 1925 the United States of Europe appeared as a more recent idea. These were concrete steps towards creating a united Europe. On the eve of the war years and during that period, leaders and population of European countries were increasingly inclined to take joint actions with Hitler to create a new European device to be able to oppose communist expansion. Mentally, Europe was ready to create a strong core that organized the European space.
\end{abstract}

\section{Introduction}

The term "collaboration" is translated from French as voluntary, intentional cooperation with the occupation authorities, and rendering them all kinds of aiding due to the political vocabulary. Pétain was the author of this term, who in July 1940 was proclaimed by the national assembly the Head of the French state. In his address to the French, Petain called on them to cooperate with the German occupation authorities. After the war, this term began to designate traitors to the interests of the State and their Homeland, who collaborated with occupiers. From the point of historical science view, it would be wrong to say that France was the cradle of this large-scale movement in Europe. In its history, Europe has experienced many wars, as part of the world, during those periods a category of

\footnotetext{
*Corresponding author: kazantsev@sibstrin.ru
} 
traitors stood out from among various European peoples, many of them worked diligently against the enemies of their own state. Another historical period was the Second World War, when France surrendered Paris to the Germans and was the first in Europe to proclaim a state policy of cooperation with the Nazi invaders. Today, specialists distinguish three main forms of collaboration: state-political, ideological and military. This issue has only been fragmented to date, in historical science with many reasons. The main one is the scientists' reluctance to study shamefacedly their countries' history and disclose the unpleasant truth of the history. The Polish researcher T. Sharota explains that "historians themselves recognized collaboration as a dangerous and unpleasant topic, which development can worsen the image of their own people in the world" [1]. Russian researchers created a small library of books and articles on "Russian collaborationism" during the Great Patriotic War. Logically, the collaboration of Belarusians, Ukrainians, Baltic countries, the peoples of the Caucasus, and other nationalities' representatives of the Soviet Union coexists with Russian collaborationism. "Forced cooperation" with the occupation authorities is pointed out as the main reason for Russian collaboration [2]. And it's hard to challenge, although just as hard to justify. In Russian historiography, the issues of European collaboration are presented fragmentarily, and even then political expediency and ideological preferences are seen in publications [3].

A special group of published works consists of studies by foreign experts on the issues of collaboration and participation of Europeans in the War against Russia. British historian Chris Bishop presented to the scientific community a book on the participation of ethnic Germans (Volksdeutsche) in SS battalions, formed in the territories of German-occupied states [4]. Researcher Robin Lamsden, who knows Europe well and is a resident of Austria, has collected and published unique material about foreign volunteers who served in the Wehrmacht and SS troops [5]. The formation of the infantry divisions and special-purpose divisions with the involvement of collaborators for conducting military operations and the German battle formation were described in S.M. Mitcham paper [6]. The British researcher Mark Edel devoted his work to the difficult choice of a Soviet soldier, sandwiched between the victorious Wehrmacht and the Stalinist repressive machine [7]. An American John Hickman literally dissected the collaborator's behavior model, focusing on the realized or missed opportunities of the "traitors" themselves, based on specific facts from the 18th to the 21 st centuries [8]. Earlier, attempts were made to literally rehabilitate the policy of collaboration, at least for individual countries, like Denmark [9]. It can be assumed that the rejection of collaborationism is weakening in the historical memory of the less affected peoples in World War II, but a group of American researchers concluded that the memory of generations fades even with respect to such significant issues as war, occupation, collaboration [10].

The entire second half of the twentieth century, Russia needed faithful allies and formed a circle of its supporters, mainly among the Eastern Europe countries. As a result, the ideas of the USSR unity and the countries of Eastern Europe dominated in scientific and journalistic literature. Gradually there was a strong opinion of the "fraternal peoples" unity took shape in the conditions of a joint struggle against the German occupiers, and the main attention was focused on the study and generalization of the "resistance movement" experience of European peoples against Nazi Germany It is possible and necessary to raise the question both, about the resistance movement experience in Europe and about its ritual nature Refusing the previous approaches.

The purpose and objectives of the work: to investigate the main causes and motives of mass collaboration in European countries during the Second World War: to determine the characteristic features of this phenomenon, as well as to reveal how much government policy provoked citizens to agree with the occupying German authorities and which form of collaboration dominated. 


\section{Results}

Mentally, European man has recognized himself as part of a single space, under one-man rule for centuries: the Roman Empire, the empire of Charlemagne, the Holy Roman Empire. The imperial idea initially suggested the European peoples' unification under the auspices of a strong center. The second component of the European mentality was built on the idea of Eurocentrism, proclaiming the superiority of European nations and Western European civilization. And although the ideals of Eurocentrism were heavily crowded in the twentieth century, the historical development path of Europe seemed to be exemplary, which were tried to imitate by other countries. Europe and human progress were perceived as synonyms. The impressive scientific, technical, and economic successes of Europe inspired optimism and faith in progress.

Proclaimed in 1871, the ruling elite of the German Empire made plans to create "Middle Europe", which incorporated the economic union of Germany, Austria-Hungary, Belgium, Holland, Denmark, Poland and trimmed France. Germany intended to expand its territorial holdings at the expense of Russia, Poland, Finland, the entire Baltic States, Ukraine, Belarus, Crimea and the Caucasus [11]. Such a "Middle Europe" was to be the War result and provide Germany with the role of European leader. It was supposed to draw military and economic borders across the entire continent in the form of a "Chinese wall". These borders were to separate Germany from France and Russia from Germany, stretching from north to south. Such a European order was supposed to be the world system basis of relations between countries based on German hegemony. Even the defeat of the German Empire in the First World War did not change the attitude of the Germans towards the issue of the European system. In 1923, the manifesto of the Austrian political scientist Kudenhove-Kalergi "pan-Europe" was published. The author meant a political Europe different from geographical by pan-Europe. In his opinion, Europe went beyond its geographical borders, which led to the emergence of several power fields with the same European roots. Now it's time to consolidate Europe and create a pan-European union. This idea received the support of European politicians. In early 1925, the idea of the European United States appeared. This was another, but unsuccessful step towards the creation of a united Europe [12].

The idea of the European United States was not realized, as it prevented the establishment of an imperial form of government in Europe with Hitler coming to power in Germany. The ideologists of the Third Reich put the main point in the statement of people biological inequality, and promoted the collective superiority of peoples with European roots. So in the minds of Europeans, the belief that they belong to the "higher civilization" was implanted, demanding to create a new Europe without subhuman. The second idea that united European countries was anti-communism. Daily propaganda turned the USSR into the main enemy of Europe. Undoubtedly, there were opposition forces in Germany and in all European countries, but they were a minority. Hitler dealt a crushing blow to the German Communist Party, just a month after coming to power. The politicians of European countries and most of the European population were tolerant of such massive Nazi actions or tacitly approved their actions.

We should note that France and Great Britain were in a state of "strange war" with Germany from September the 3d, 1939. In fact, this was a direct connivance of Germany. Hitler noted that Europe did not reject him, did not fight selflessly with him. In the incomplete nine months of the "strange" war, the Germans occupied Poland, Denmark and Norway. On May 10, 1940, Germany launched an offensive on Belgium, the Netherlands, Luxembourg, and France. The sit-in war was over. As a result, 11 European countries conquered the Germans from September 1939 to June 22, 1941 (German attacked on the USSR). An important question, how serious and real was the resistance of European states 
to German occupiers, arose. Let's turn to the specifics. Denmark fought back only 6 hours, Norway fought back 24 hours, France capitulated after 11 days, Belgium fight back 17 days. Poland was conquered by the Germans in one month and five days.

The losses of the German army amounted to 2 killed people and 10 wounded during the capture of Denmark; Belgium lost 18.7 thousand people; the German army lost a little more than 45 thousand soldiers and officers until the moment of France's copulation. In the war with Poland, the German ground forces lost 16.8 thousand people killed and 36.5 thousand wounded. The data on military losses are not always accurate, but it is important for us to see the scale of "military operations" in Europe. It is difficult to dispute the fact that on the general field of World War II, the losses of Europeans seem scanty, and the resistance of European states to Germans looks like a ritual action where more than 71 million people died. It should be especially noted that the German occupiers behaved in the occupied territories of Europe underlined delicately, especially where they were not resisted. The military was ordered to appear on the streets of European cities in polished shoes, an ironed uniform, and a fresh shirt with no hint of robbery and looting, no violence against women. In this way, the Germans emphasized that they were not conquerors of the European states, but that they carried out the great mission of creating a new Europe under the auspices of the German nation.

The leaders of European states proclaimed a policy of joint action to create a new European system with the Germans. It is important to emphasize that the 1930s were characterized by serious changes in the economy and politics of European countries. In 1936, out of 27 European countries, only 10 retained bourgeois-democratic freedoms, and then in a significantly reduced form. Fascist regimes were established in Italy and Germany; attempts at a fascist coup were made in France. The management system has fundamentally changed - from parliamentarism to dictatorial regimes. Military regimes were supposed to strengthen the economy and ensure public stability and national security by terrorist methods. In fact, the establishment of military regimes brought Europe closer to a new war.

Some European states positioned themselves as an ally of great Germany. The war with the USSR was declared by Italy, Romania, Croatia, Slovakia; Finland joined on June 25, and Hungary on June 27 together with Germany on June 22, 1941. The governments of these countries sought patronage from Germany, hoping that their peoples would become an integral part of the new Europe. Other European States positioned themselves as opponents of Hitler's Geramnia, but they could not provide decent resistance to the Germans. Such states went on conscious cooperation with the invaders once in the zone of occupation. An example of such public policy has been demonstrated by France. The president of the country, Marshal Petain formed a puppet government - the Vichy regime after Paris was surrendered. The policy of statesmen predetermined the alignment of forces in France. Supporters of the Vichy regime, or collaborators, turned out to be several times more than their opponents. The France example was followed by the governments of other European countries. They paid all the costs of the German occupation forces stationed in their territories, so during the war years Germany received financial assistance of 80 billion marks. In addition, France supplied the German army with about 4 thousand aircraft, about 10 thousand aircraft engines, more than 52 thousand trucks. In the first half of 1941, every 5th tank of the Wehrmacht troops was manufactured at the Skoda Czech plant. Holland produced half of all industrial products by German military orders. The Second World War was a War of engines, so the problem of oil and oil products was relevant. Romania became one of the fuel suppliers for German tanks [13].

Ethnic cleansing program was carried out in Europe at the initiative of the Third Reich leadership. Mass shootings of Jews, Gypsies, Slavs are known. This program also involved the "infusion" of Aryan blood into peoples of European descent. So there was a special, so- 
called horizontal collaborationism, when women of the occupied countries copulated with German officers and soldiers. This is one of the most cruel and dramatic pages of European history. According to the official data, only in France, 5 thousand women were shot for communication with the German occupiers and up to 30 thousand were in prisons after the war. The most widespread form of punishment for horizontal collaborationism was public head shaving. In Norway, about 100 thousand women were suspected in intimate relations with the Germans. After the war, 14 thousand of them were convicted and others were deprived of citizenship. Out of the 12 thousand born babies, 8 thousand were selected for "racially clean" Germany families. Later, these women of European countries got apologize [14]. Well, they should be judged when all of Europe "slept in the same bed" with Germany, agreeing to create a new, united, strong civilization.

\section{Discussion}

It is important to take into account the fact that the European man was ready to create a united, holistic, renewed Europe, under the auspices of a strong center. But the role of such a center historically claimed in turn: Spain of the XVI - the first half of the XVII century; the great century of France is called the time from the middle of the XVII - and the whole XVIII century; England domination was of the middle of the 19th century until the First World War. Since the end of the XIX century the German Empire, formed in 1871, entered the race of leaders. It was one-third more populous than France, but it was France that the lands of eternal territorial rivalry, Alsace and Lorraine, were transferred to after World War I. The historical dispute about the nationality of these territories, located in the eastern part of France, gradually turned into a category of centuries-old disputes. Here important lines of tension in European politics intersected, many international organizations and institutions of international activity were located here. But the main thing on this territory was the Germans and French.

The French language was banned here, while these territories were called the "imperial lands" of Germany and after the First World War with the transferring the lands to France, the Germans began to be oppressed here. Nevertheless, this territorial space has turned into a large ethnic cauldron. It so happened historically that mixed families were not infrequently created in this disputed territory, whose children referred to both Germans and French, were fluent in two languages with double-mental mind. In the summer 1940, Germany again occupied Alsace-Lorraine and dominated here, until the liberation of these lands by Anglo-American troops in 1944. The little-known history of the Alsace-Lorraine inhabitants' service in the troops of Nazi Germany during the Second World War is very revealing. Over 130 thousand went to serve in the Wehrmacht and the SS, though about 40 thousand from the number of draftees evaded military service. There were mainly ethnic French among the deviators [15]. The population with German roots considered it an honor to serve the cause of great Germany. And in August 1942, a Decree was issued, that proclaimed the third generation of Alsace residents, whose relatives were natives of Germany, were declared purebred Germans, and were required to bear military service.

The fate of the people living in the borders of Schleswig and Holstein was no less dramatic, who were under the control of Denmark before 1864, and then transferred to the joint management of Austria and Prussia parts of the German Empire since 1871. Since 1920, the northern part of Schleswig was transferred from Germany to Denmark. More than 1.5 million people lived here and their vast majority was ethnic Germans at the beginning of the XX century. Two ethnic cauldrons of Europe: Alsace - Lorraine, Schleswig and Holstein gave an idea of the reasons for the massive collaboration in Europe. After the First World War, the situation in the Danzing corridor zone was not less difficult where the German population predominated. The police were Polish, and the League of Nations 
management system was in Danzing. It can be argued that the natural course of history and the First World War results laid the foundation for the mass discontent of Europeans, who understood the arrival of the Nazi troops as a restoration of historical justice. Among those who deliberately went into cooperation with the occupying German authorities were representatives of different countries and peoples of Europe. Famous historian M.I. Semyaryaga gives compelling reasons for this fact in his fundamental work. Only in the SS troops during the Second World War served: 40 thousand Dutch, 25 thousand Latvians, 12.5 thousand Estonians, 10 thousand French, 8 thousand Norwegians, and in addition there were Belgians, Danes and citizens of other countries. In total, about 2 million Europeans fought on the side of Germany, who voluntarily joined the Nazi army. The historian M. Semiryaga believes just this category of collaborators deliberately served the interest of the German invaders and did the most harm to the vanquished, since "everyday" cooperation was forced and did not harm the fundamental interests of their Motherland, but only mitigated the hardships of the occupation [16] .

In their efforts to create a new Europe, the German leadership relied on the use of an important reserve - Volksdeutsche, the Germans who lived in European countries outside their historical homeland and who retained their German identity: they knew the language, saved their culture and ways of life. According to various sources, up to 30 million Volksdeutsche lived outside Germany. Those Germans who lived in Germany since the German Empire formation (1871 - 1945) were called the "Reichs daughter". There were 79 million people by the beginning of World War II. From a comparison of these two categories, one can see how large and powerful the German reserve was, who lived in other countries by Diasporas. With the advent of the German occupation forces on foreign territory, the Volksdeutsche received a Folkslist, a document giving the right to a number of privileges in comparison with the local population. It is known that every privilege has to be fulfilled. The male population of Volksdeutsche became the core of the emerging SS battalions. In order to help Germany, France formed the Walloon volunteer tank division, the Charlemagne grenadier division. Belgium formed the Viking tank division together with Denmark and the Flemish Legion together with the Netherlands, etc. It is significant that such military formations were named so that their nationality could be easily determined: "Galicia", "Bohemia and Moravia", "Denemarck", "Nordland", "Netherlands", "Charlemagne", etc. [17].

The birthplace of many European undertakings was France. Here, the significant "resistance movement" appeared, there were attempts to resist the Germans in Greece, Yugoslavia, Poland. It was called the partisan movement. Moreover, the partisan movement was much more selfless and large-scale in the fight against the invaders than the resistance movement. About 300 thousand Yugoslav partisans and about 29 thousand Albanians were killed in the struggle against the invaders. This movement existed throughout the war. It is no coincidence that the period of 1941-1945 became to know as the people's liberation war of Yugoslavia [18]. Therefore, it should be noted once again when the resistance movement appeared in France and how it developed. The Soviet government announced the recognition of the Free France National Committee, headed by General de Gaulle in September 26, 1941. This was tantamount to establishing an alliance with the committee. The USSR pursued a consistent line towards the restoration of independent and sovereign France. However, only at the end of 1943 - beginning of 1944 the Committee for National Liberation developed vigorous activity. Prior to this, there were small scattered groups that dreamed of a free France, but practically did not do much for this. On June 6, 1944, a second front was opened by the Anglo-Americans, and the Iasi-Kishinev operation on August 20, 1944. Red Army began its liberation campaign in Europe. Undoubtedly, these events revived the opponents of the state-political collaboration in France, and the course of the war showed the inevitable defeat of Germany [19]. 
It can be stated that the leaders of the Euro-European states followed a policy of concerted action to create a new European structure with the Germans, having squeezed a sense of national pride until the beginning of 1944. For the results of state-political collaboration, the politicians of several European countries had to answer. So the head of the collaborationist Vichy government, formed in the south of France, Henri Philippe Petain convicted and sentenced to life imprisonment after the war was. In Norway, V. Quisling served as Minister-President from 1942 until the end of the war. According to the court, he was shot for high treason and cooperation with the occupying authorities of Germany. During the German occupation of the Netherlands, the puppet government was led by Anton Adrian Mussert. After the war he was arrested by allied forces and executed.

An important reason for the massive collaboration in Europe was the increase people's fears of the communist principles' expansion in Europe. Despite the efforts of Soviet diplomacy, Soviet Russia remained on the sidelines and hardly fit into international relations by the beginning of the 30 s. Soviet Russia tried to form its image as a fighter power for organizing international cooperation to strengthen peace. Russia wanted the States sign the convection on the definition of an aggressor and military threat prevention. But the Soviet initiatives were ignored and did not find support because the country's international situation was very unstable.

The Soviet Union was not able to reach an equal agreement on military cooperation at the negotiations of the three powers' military missions, held in Moscow in August 1939. Despite the fact that, the USSR agreed to place 136 divisions, up to 10 thousand tanks, more than 5 thousand combat aircraft against the aggressor in Europe in the case of a war, neither Great Britain nor France decided to establish equal relations with the Soviet. It seemed that the non-aggression treaty with Germany provided the USSR with an opportunity to stand apart from the war, rather than the agreement with Great Britain and France on mutual assistance that would force the country to enter the war actions. It seemed that the conclusion of the Molotov-Ribbentrop Pact was forced and logical in those historical conditions. Already, the Red Army occupied the territories of Western Ukraine and Western Belarus in the conditions of the Second World War, in September 1939. Soviet power was proclaimed at the territories of the Red Army presence. The Supreme Soviet of the USSR introduced Western Ukraine and Western Belarus into the Union States on November 1, 1939. In September 1939, the Soviet government invited Lithuania, Latvia and Estonia to sign mutual assistance agreements with the USSR. The Soviet Union received the right to establish naval bases and airfields in Estonia and Latvia, and land and air forces base in Lithuania. The Soviet system was immediately established throughout the territory of the USSR countries: private property was eliminated, the use of wage labor was excluded, and a Soviet-style political model was built. These events further turned out into anti-Soviet sentiment among the western people.

The German propaganda machine skillfully used the anti-communist ideology in its activities. Anticommunism was aimed primarily at discrediting the practice of socialist construction in the USSR, as a system of views. The highest peak of anti-Soviet propaganda occurred during the Second World War. Joachim Hoffmann suggested that the Nazis underestimated the true potential of A. A. Vlasov, otherwise, he would have significantly broken the almighty state machine of the USSR, having received carte blanche for anti-Soviet propaganda. [20]. Professional work brought many millions of people in Europe to wave of demonstrations. The communist bugbear acted on Europeans more strongly than the threat of German occupation. The forms of work with the population were very diverse: conversations, mass media, and radio. A special role was given to poster activities. Posters were printed with a caricature of Soviet politicians, a dictatorial form of government and a lack of democratic principles in the USSR, mass famine in Russia and its victims. 
In contrast to these phenomena, the idea of a new Europe creating under the leadership of the German National Socialists was put forward. A tough alternative was being suggested for the Europeans: either Hitler or Stalin, and for the most part they chose the first. The high standard of living, centuries-old tradition of private property and inspired biological superiority over the Russia peoples, everyday propaganda turned the USSR into the main enemy Europe. Moreover, in practice, a number of States were sure in democratic and proletarian revolutions immediately after the First World War. Germany, Hungary, Estonia, and others were among such countries. European politicians widely cultivated the term "export of revolution" to Europe from Russia, as a way of ideological population's treatment.

Back in November 1936, Germany concluded the Anti-Comintern Pact with Japan and invited third countries to engage in a joint defensive struggle and called for the severest measures to be taken against those, who acted in the interests of the Communist International. The parties agreed that none of them would sign bilateral agreements with the USSR. The German government took into account that Great Britain and the USA took a hostile attitude towards our country, planning the war against the USSR. The Berlin government had hopes for a complete foreign policy isolation of the Soviet Union Secretly and explicitly appealing to them. And these plans were practically realized, the population of the mostly whole world turned out to be hostile to Russia. Speaking the truth, at the time of the German attack on the USSR, and after W. Churchill radio speech, a rally was held in London on June 23, 1941, which participants demanded support the USSR from the British government. Thousands of New Yorkers took the initiative to create a fund to help the Soviet Union at the rally on July 2, 1941. All other European states accepted the German attack on the USSR without much regret. This attack seemed as a logical continuation of the anti-communism policy. Thus, the historical perspective set Europeans on the conscious comprehensive support of Nazi Germany during the Second World War. Hitler and his propaganda machine managed to "call" the Europeans on a "crusade" against Soviet Bolshevism. The Catholic Church supported Hitler and the popular war of Europeans against the communists of the USSR.

The Second World War in its scope, actions and consequences was terrible. It was a drama of universal scale. The motives of human behavior in war have been studied a little. It is not worthwhile to strictly judge a person found out him in an extreme life situation. It is another matter to investigate and understand the main causes of mass collaboration in Europe, in order to determine the characteristic features of this phenomenon, and also to determine how much government policy provoked citizens to conciliate and conscious cooperation with the occupying German authorities. Answers to these questions help to recreate the true history of the Second World War, more precisely determine the goals, interests, reasons, balance of power and the war results. The countries creation of the eastern bloc under the auspices of the USSR in Eastern Europe after the Second World War, contributed to the so-called "brotherly family" of peoples formation, which turned out to be a "false brotherhood". The liquidation of private property and the construction of the Kremlin socialism model in Eastern Europe turned out to be a serious historical miscalculation. But there is no reason to be ashamed or repent for military modern Russian operations in Europe, as a successor of the USSR.

\section{Conclusion}

A retrospective analysis suggests that the main cause of the Europeans mass collaboration was the vital dilemma to maintain the stability and development of the traditional socioeconomic model, and to follow Germany, which had already established its hegemony in Europe, or agree to a communist experiment, using the Russian one. Mentally, Europe was 
more ready to create a strong core, represented by Germany, organizing a new European space. During the Second World War, the state policy of European countries was subordinated to two trends. On the one hand, the spreading of the communism threat in Europe, which could have been prevented by a strong dictator, on the other hand, proGerman politics grew into state-political collaboration, which was carried out through government bodies. Typical examples of state collaboration were demonstrated by France, Denmark, and the Czech Republic, Moravia, Norway and other countries.

State policy and the ordinary consciousness of citizens of European countries have formed a tolerance for aggression from Germany. As a result, both statesmen and the most part of the citizens in European states were ready for voluntary and informed cooperation with the German occupiers. None of the European countries, except Great Britain, had a serious military opposition to Germany, and the "resistance movement", with the exception of the partisan movement, was largely ritual to the new German order in Europe. Thus, mass collaborationism was a natural consequence of the state-political system development in Europe on the eve of the Second World War and during its period.

\section{References}

1. S.G. Verigin, Traitors or victims of war: Collaborationism in Karelia during the Second World War 1939-1945 (Petrozavodsk, Publishing House of PetrSU, 181, 2012)

2. V.A. Perezhogin, War and society, 1941-1945, Book 2 of Ch. Questions of collaboration, 293-305 (2004)

3. S.I. Drobyazko, O.V. Romanko, K.K. Semenov, Foreign formations of the Third Reich. Foreigners in the service of Nazism: a history of European collaboration (AST Astrel, 832, 2011)

4. K. Bishop, Foreign divisions of the Third Reich, Foreign volunteers in the SS troops 1940-1945 (2006)

5. R. Lumsden, La vera storia delle SS (Roma, Newton Compton, 2006)

6. S.M. Mitcham, German Order of Battle (Stackpole Books, 2007)

7. M. Edele, Stalin's Defectors: How Red Army Soldiers Became Hitler's Collaborators, 1941-1945 (Oxford University Press, 240, 2017)

8. J. Hickman, The occupier's dilemma: Problem collaborators, Comparative Strategy (2017) DOI: 10.1080 / 01495933.2017.1338480

9. P. Giltner, Success of Collaboration: Denmark's Self-Assessment of its Economic Position after Five Years of Nazi Occupation, Journal of Contemporary History 36 (3), 485-506 (2001) doi: 10.1177 / 002200940103600305

10. C.B. Stone, A. van der Haegen, O. Luminet, W. Hirst, Personally relevant vs. nationally relevant memories: An intergenerational examination of World War II memories across and within Belgian French-speaking families, Journal of Applied Research in Memory and Cognition 3(4), 280-286 (2014) doi: 10.1016/j.jarmac.2014.08.08.002

11. The history of Russian foreign policy, The end of the nineteenth and the beginning of the twentieth century (1999)

12. Yu.I. Kazantsev, International relations and foreign policy of Russia (XX century) (Siberian agreement. Phoenix Rostov-on-Don, 126, 2002)

13. A.Shpirt, Oil resources of Germany and its vassals, Military Thought, 61-68 (1941) 
14. W. Helmut, Rechte in der Rada: "Swoboda", Nationalismus und Kollaboration mit den Faschisten in der Ukraine und in Europa (Edition Ost Im Verlag Das, 2013)

15. K. Heller, G. Simpson, The Hidden Histories of War Crime Trials (Oxford University Press, 2013)

16. M.I. Semiryaga, Collaborationism: nature, typology and manifestations during the Second World War (2000)

17. V.V. Kozhinov, Russian history, Century XX Vol 1, 1038 (2019)

18. M. Gojko, The Great Cue Ball at the Yugoslav Proclamation 1941-1945 (People's Kig, Belgrade, 1989)

19. Soviet-French relations during the Great Patriotic War of 1941-1945, Documents and materials, Moscow (1960)

20. Joachim Hoffmann: Die Tragödie der 'Russischen Befreiungsarmee' 1944/45, Wlassow gegen Stalin, Herbig Verlag (2003) 